\section{Ecotoxicology}

May 2008, Volume 17, Number 4 : Pages 235-245

http://dx.doi.org/10.1007/s10646-007-0190-9

(c) 2008 Springer. Part of Springer Science+Business

Media

The original publication is available at http://www.springerlink.com
Archimer, archive institutionnelle de l'Ifremer http://www.ifremer.fr/docelec/

\title{
In-situ microcosms, a tool for assessment of pesticide impacts on oyster spat (Crassostrea gigas)
}

\author{
Sabine Stachowski-Haberkorn ${ }^{1}$, Françoise Quiniou ${ }^{2}$, Morgane Nedelec ${ }^{3}$, René Robert ${ }^{4}$, Gwendolina \\ Limon $^{5}$ and Denis de la Broise ${ }^{1, *}$
}

${ }^{1}$ Lumaq, Université de Bretagne Occidentale, 6 rue de l'université, Quimper, 29334, France

${ }^{2}$ Département Biogéochimie et Ecotoxicologie, IFREMER-Centre de Brest, BP 70, Plouzané, 29280, France

${ }^{3}$ Agrocampus site de Beg-Meil, La Cale, Beg-Meil, Fouesnant, 29170, France

${ }^{4}$ Laboratoire de Physiologie des Invertébrés Marins, IFREMER, Presqu'île du Vivier, Landunvez, 29840, France

${ }^{5}$ Laboratoire Idhesa, Technopôle Brest-Iroise, 120 avenue Alexis de Rochon, BP 52, Plouzané, 29280, France

*: Corresponding author : Denis de la Broise, email address : denis.de-labroise@univ-brest.fr

\begin{abstract}
:
Effects of the herbicide Basamaïs (bentazon) and the fungicide Opus (epoxiconazole) on oyster spat (Crassostrea gigas) were assessed using in-situ microcosms in a field experiment lasting 13 days. Sixweek-old hatchery spat (mean size $1.1 \mathrm{~mm}$ ), previously collected on PVC plates, was immersed in glass bottles filled with $200 \mu \mathrm{m}$ filtered seawater. Bottles were maintained underwater at $6 \mathrm{~m}$ depth and their water content changed every other day. Growth, measured as shell area index increase, was $126 \pm 4 \%$ in the control bottles. While no growth differences were observed between control and individual pesticide treatments at $10 \mu \mathrm{g} \mathrm{I}^{-1}$, oysters treated with a mix of $10 \mu \mathrm{g} \mathrm{I}^{-1}$ Opus and $10 \mu \mathrm{g} \mathrm{I}^{-1}$ Basamaiis showed a 50\% growth reduction compared with the control $(P<0.0001)$, suggesting a synergistic effect of these contaminants. Laboratory controls in microcosms maintained in a water bath with filtered natural light, were not significantly different from in-situ microcosm controls in the field, for organic weight content or growth. This in-situ experiment in microcosms allowed us to conclude that: (1) oyster spat can achieve significant growth in bottles immersed in situ without supplementary food; (2) this microcosm system is reliable and easy to use for environmental toxicity tests with C. gigas spat; (3) such microcosm systems can also be run in a laboratory water bath instead of more technically difficult immersed field experiments; (4) the synergistic effect observed here, at a concentration simulating a peak agricultural runoff event, suggests that the impacts of pesticides could be a real threat for oysters in estuarine areas.
\end{abstract}

Keywords: Microcosm - Oyster - Toxicity - Pesticide - Bentazon - Epoxiconazole

\section{Introduction}

Among aquatic organisms, bivalves and especially oysters are frequently used as sentinel organisms to assess the toxicity of a large variety of contaminants in the marine and estuarine water or sediments. Their sedentary life and filter-feeding behaviour particularly expose them to environmental parameter modifications (salinity, temperature, nutrients etc.) as well as to contamination by pollutants. France is the largest producer of oysters in Europe and the fourth largest in the world. Among the 130 000 tons produced per year, about $84 \%$ are issued from natural settlement of oyster larvae at metamorphosis (spat) (Girard et al., 2005). Many 
laboratory studies have been published on the earlier development stages where oyster embryos and larvae were used for toxicity tests with a focus made on shape abnormality criteria (His et al., 1999; Lyons et al., 2002; Geffard et al., 2003; Geffard et al., 2004; da Cruz et al., 2007; Losso et al., 2007; Paixão et al., 2007). Other parameters analysed in larval toxicity bioassays include: biochemical biomarkers (Damiens et al., 2004), delays in D shape development (Nice et al., 2000), contaminant accumulation and metallothionein induction (Geffard et al., 2003), and success of metamorphosis (His et al., 1997). On adult oysters, other parameters have been measured to assess pollutant toxicity: haemocyte activity (Auffret and Oubella, 1997; Gagnaire et al., 2004), genetic damage such as aneuploidy (Bouilly et al., 2004; Bouilly et al., 2007), and effects on down- or up-regulation of genes (Tanguy et al., 2005). Accumulation of toxicants has also been monitored in various tissues of adult oysters (Li et al., 1997; Oliver et al., 2001), and histopathological evaluation made of gametogenesis in relation to toxicant exposure (Wintermeyer and Cooper, 2007). However, there is a lack of information on spat sensitivity to pollutants currently detected in marine environments, and only a few studies on oyster spat have been reported. Oyster spat provides the ability to work with settled organisms that are easier to handle and less fragile than larvae. Spat thus allows longer exposure periods to toxicants compared with larvae for which tests can only be run for 24 to $72 \mathrm{~h}$ periods. Although many studies have demonstrated the toxicity of pollutants, most were done indoors, in controlled conditions. As such laboratory studies do not really simulate the physical and chemical conditions of the natural environment, it should be asked how representative their experimental data are of natural conditions, and thus to what extent we can apply the conclusions of these experiments to natural systems. A few studies have been published on in situ pollution impact experiments in open systems on larvae (Geffard et al., 2001; Quiniou et al., 2007) and juveniles (Arnold et al., 2004; Bolton-Warberg et al., 2007). Some in situ studies in open systems were also made on adult oysters (Christl et al., 2004), 
although many of these only dealt with bioaccumulation (Avery and Dunstan, 1996; AmiardTriquet et al., 1998; Riedel and Valette-Silver, 2002; Clara Reboucas do Amaral et al., 2005). One possible complication of in situ experiments using open systems, is that shellfish are exposed to pollutants already found in the local environment in addition to any tested in an experiment. In situ open systems can be used to test the possible toxicity of chemicals prior to their use, as shown by His et al. (1996) who found no toxic effect of a novel antifouling material on oyster culture. However, such studies imply the experimental pollution of a site with the chemical under test. Other approaches are therefore needed to evaluate the toxicity of xenobiotics in uncontaminated areas, using non-open systems, maintained under conditions as close to natural as possible.

Numerous pollutants can be found in marine environments including: polycyclic aromatic hydrocarbons (PAHs), gasoline formulations, organophosphates, polychlorinated biphenyls (PCBs), heavy metals, antifouling paints and pesticides. Pesticides are widely used throughout the world and often encountered in coastal waters. Herbicides and fungicides can arrive in the sea following spray-drift, leaching or run-off from urban and farming treated areas. Mixtures of such compounds can result in synergistic, antagonistic or additive effects, as described by Fernandez-Alba et al. (2001). Banks et al. (2005), for example, suggested a synergistic toxicity of atrazine and diazinon on the daphniidae Ceriodaphnia dubia at environmentally representative concentrations.

To address the question of pesticide effects on oyster spat exposed in natural conditions, the purposes of this study were:

1. The development and evaluation of an in situ tool, which could simulate the natural surrounding conditions and allow the maintenance of young and sensitive oyster spat with low mortality and efficient growth. 
2. The assessment of the toxic effects of two pesticides, the fungicide epoxiconazole (Opus ${ }^{\circledR}$, BASF) and the herbicide bentazon (Basamaïs ${ }^{\circledR}$, BASF) on Crassostrea gigas spat mortality, growth, and organic weight content.

3. A laboratory trial to determine whether this type of microcosm could be used in indoor experiments under controlled but close to natural conditions.

\section{Materials and methods}

To assess the impact of pesticides on oysters, 6-week-old spat was maintained in bottles immersed in situ, and exposed to Opus and Basamais at $10 \mu \mathrm{g} \mathrm{L}^{-1}$ or $70 \mu \mathrm{g} \mathrm{L}^{-1}$ (pure active substance), or to a mixture containing each at $10 \mu \mathrm{g} \mathrm{L}^{-1}$. The final dry weight, ash content, and increase in shell area were evaluated. Spat mortality during experiment was also assessed by oyster counts at the beginning and end of the experiment. Chlorophyll $a$ (Chl $a$ ) content of the bottles was measured over a two day period to assess food availability.

\section{Biological material}

Production of pediveligers:

Diploid oyster spawning was induced at Ifremer experimental hatchery of Argenton (Brittany, France), during the first week of May 2006. Initial D larvae density was 220 larvae. $\mathrm{mL}^{-1}$; larvae developed at $25^{\circ} \mathrm{C}$ in $450 \mathrm{~L}$ tanks with a $50 \mathrm{~L} \cdot \mathrm{h}^{-1}$ throughflow of $5 \mu \mathrm{m}$ filtered seawater enriched with phytoplankton ad libitum. Nine days after spawning, young umboned larvae were collected by sieving, thinned to 110 larvae. $\mathrm{mL}^{-1}$ and maintained for 10 days. Forty million pediveligers were thus obtained. 
Preparation of spat plates:

To reduce the risk of losing the whole larval batch, it was split into two and settled simultaneously at two sites: the Ifremer experimental hatchery at Argenton, and the Agrocampus experimental hatchery at Beg-Meil (Brittany, France). Settlement was achieved in the following manner at each site: 19 days after spawning, 60 sand-papered ivory PVC plates (dimensions: $255 \mathrm{~mm}$ length, $28 \mathrm{~mm}$ width, $2 \mathrm{~mm}$ thickness), were hung in a $200 \mathrm{~L}$ larval rearing tank to allow settlement at $20-22^{\circ} \mathrm{C}$.

In Argenton, five days after the end of the settlement (29 days after spawning), the 60 PVC plates were transferred into a $100 \mathrm{~L}$ open water flow tank (50 L.h ${ }^{-1}$ renewal), and the spat were fed daily with cultures of Isochrysis aff. galbana and Chaetoceros calcitrans at a 1:2 ratio. Four days before the beginning of the outdoor experiment, temperature was gradually decreased to $18^{\circ} \mathrm{C}$, by $1^{\circ} \mathrm{C} \cdot$ day $^{-1}$.

In Beg Meil, the 60 plates were maintained in the $200 \mathrm{~L}$ rearing tank at $20^{\circ} \mathrm{C}$, with a renewal of $100 \mathrm{~L} 1 \mu \mathrm{m}$ filtered sea water every other day, until the beginning of the outdoor experiment. They were fed daily with Isochrysis aff. galbana and Skeletonema costatum, at a 9:1 ratio.

Six weeks after spawning (14 June 2006), groups of 4 or 6 plates, including 2 or 3 from each settlement site, were prepared to go in the microcosms. Some oysters were detached from the plates using a razor blade so as to retain animals on a single $150 \mathrm{~mm} * 28 \mathrm{~mm}$ surface (100 to 800 oysters per plate). The plates were then transported to the experimental site, maintaining damp conditions during transport.

\section{Microcosms}

Microcosms consisted of 2.3 L glass bottles, filled with $2 \mathrm{~L}$ of $200 \mu \mathrm{m}$ filtered fresh seawater from the surface layer at the field site, enclosed with about $300 \mathrm{~mL}$ of air. Pesticides were 
added to the appropriate treatment bottles, and spat plates were placed inside (1 plate/bottle) (Figure 1). Plate dimensions were designed based on bottle height and bottleneck diameter in order to trap plates and avoid any movement. This system limited any damage to oyster spat during experiment. One plate was put in each bottle, the groups of (4 or 6) plates therefore now corresponded to groups of bottles which were subsequently used as sets of replicate microcosms for the different treatments. Forty microcosms were prepared: 36 for the outdoor experiment in situ (6 controls, and 6x5 pesticide tests), and 4 for the indoor experiment (laboratory control).

Outdoor 'in situ' experiment

Microcosms were hung on a $3 \mathrm{~m}$ diameter circular stainless steel frame, which could carry 36 bottles. The frame was anchored to the sea floor, on a $400 \mathrm{~kg}$ concrete block, and suspended from a surface buoy that allowed the bottles to remain at $6 \mathrm{~m}$ depth, regardless of the tide. The frame was located in Port-la-Forêt Bay, south Brittany, France (4752'12”N, 0358’35”W). The 6 replicate microcosm bottles of each treatment were distributed all around the frame. Every other day (on days 2, 4, 6, 9 and 11), the frame was hauled out of the water. The entire seawater content of each bottle was collected in a tank for proper disposal, and replaced with fresh $200 \mu \mathrm{m}$ filtered seawater. Pesticides were added to the appropriate treatment microcosms, and the frame was re-immersed. Bottles were finally collected on day 13 for full analysis.

\section{Indoor experiment}

On the first day of the experiment, 4 control microcosms were immersed at $18^{\circ} \mathrm{C}$ in a thermostat-regulated glass water-bath in the laboratory. In order to simulate underwater light conditions at 5-10 m depth, this tank was placed behind a south-facing window equipped with 
2 filters: a UV Filter \#3114 and a blue Aquamarine Supergel ${ }^{\mathrm{TM}}$ filter \#363, both from Rosco Laboratories (Stamford, CT, USA). The sea water content was changed in the same manner as for the outdoor experiment.

\section{Pesticides}

Pesticides tested in this study were the commercial formulations of the fungicide epoxiconazole (Opus $\left.{ }^{\circledR}, \mathrm{BASF}\right)$ and the herbicide bentazon (Basamaïs $\left.{ }^{\circledR}, \mathrm{BASF}\right)$. These pesticides were selected, and their test concentrations defined according to preliminary tests run on $C$. gigas larvae and embryos (unpublished data). Concentrations given represent those of the pure active substances. Pesticide stock solutions $\left(10 \mathrm{mg} . \mathrm{L}^{-1}\right)$ were prepared in seawater that had been filtered through a $0.22 \mu \mathrm{m}$ membrane and autoclaved for $20 \mathrm{~min}$ at $121^{\circ} \mathrm{C}$. Formulations of the commercial brand products were diluted directly in this seawater and agitated for $48 \mathrm{~h}$ using a magnetic stirrer. These solutions were sampled for analysis and immediately frozen. Doses of freshly melted stock solutions were added directly to microcosm bottles just before immersion. Pesticide concentrations in the microcosms were analyzed on pooled water samples from the 6 replicate bottles of each treatment at the end of the experiment. These samples were kept frozen until analysis.

Pesticide analyses were performed by the Idhesa Laboratory (Brest, France), using on-line solid-phase extraction coupled with liquid chromatography and electrospray ionisationtandem mass spectrometry (HPLC Waters separation module 2690, Waters photodiode array 996 detector; Micromass ${ }^{\circledR}$ Quattro Ultima ${ }^{\mathrm{TM}}$ mass spectrometer). The detection limit was $0.005 \mu \mathrm{g} . \mathrm{L}^{-1}$. 


\section{Chlorophyll $a$}

In order to assess in situ microcosm feeding conditions, food availability was evaluated from Chlorophyll $a(\mathrm{Chl} a)$ measurements, first in the surface water used for medium renewal in bottles, and then two days later in the bottles.

Two liters of surface sea water $(200 \mu \mathrm{L}$ filtered) and then $2 \mathrm{~L}$ of water from the microcosms were filtered on $0.7 \mu \mathrm{m} \mathrm{GF} / \mathrm{F}$ Whatman ${ }^{\circledR}$ glass microfibre filters. Filters were stored in the freezer $\left(-24^{\circ} \mathrm{C}\right)$ until $\mathrm{Chl} a$ extraction could be performed. Working in the dark, filters were cut into small pieces and put in $15 \mathrm{~mL}$ centrifuge tubes together with $10 \mathrm{~mL}$ of $90 \%$ acetone. Filters were crushed using a glass stick and $\mathrm{Chl} a$ was extracted overnight at $4^{\circ} \mathrm{C}$. Tubes were then centrifuged for 1 minute at $2000 \mathrm{~g}$ before removing the pieces of filter, and centrifuged again for 10 minutes at $2000 \mathrm{~g}$. Chl $a$ determination was made on the supernatants using a Perkin Elmer LS 50B spectro-fluorimeter (slit width: $2.5 \mathrm{~nm}$; integration time: $60 \mathrm{~s}$; excitation/emission wavelengths: $432 \mathrm{~nm} / 671 \mathrm{~nm}$ ). Supernatant fluorescence was measured before and after acidification $(10 \mu \mathrm{L}$ of $0.3 \mathrm{M} \mathrm{HCl})$ and $\mathrm{Chl} a$ concentration was calculated using the formula of Aminot and Kerouel (2004):

$$
\text { Chl } a\left(\mu \mathrm{g} . \mathrm{L}^{-1}\right)=\left[\mathrm{K}^{*} \mathrm{R}_{\max } /\left(\mathrm{R}_{\max }-1\right)\right]^{*}\left(\mathrm{~F}^{\mathrm{NA}}-\mathrm{F}^{\mathrm{A}}\right) *[\mathrm{v} /(1000 * \mathrm{~V})]
$$

where $K$ is the calibration coefficient and $R_{\max }$ is the maximum acidification ratio. $K$ and $R_{\max }$ were calculated from the fluorimeter calibration procedure. $\mathrm{F}^{\mathrm{NA}}$ is the non acidified sample

fluorescence, $\mathrm{F}^{\mathrm{A}}$ is the acidified sample fluorescence, $\mathrm{v}$ is the acetone volume $(\mathrm{mL})$ and $\mathrm{V}$ is the volume of filtered water (L). 


\section{Image analysis of oyster}

Photographs of each plate including a measurement scale (Figure 2) were taken on the first and last day of the experiment using a Lumix Panasonic DMC-FZ20 5 megapixel camera.

For mortality assessment, at least 100 oysters per plate were individually compared between the first and last day photographs. Mortality was defined as the percentage of oyster disappearance or total transparency on the last day of experiment, compared with the first day. For size measurements, the two longest perpendicular shell widths ( 1 and L) of 50 oysters were measured using Gimp 2 software on photographs taken of each plate on the first day. The same measurements were taken on the same organisms on the last day photographs. For each oyster, the equation $1 * \mathrm{~L}$ was used to obtain two "area indexes" (Ai), for the first and last days of the experiment. For each oyster, the increase of the area index during the experiment was defined as growth $(\mathrm{G})$ :

$$
\mathrm{G}(\%)=\left[\left(\mathrm{Ai}_{\text {last day }}-\mathrm{Ai}_{\text {first day }}\right) / \mathrm{Ai}_{\text {first day }}\right] * 100
$$

\section{Spat organic weight content $(\mathrm{OW})$}

On the last day of the experiment, after taking photographs, the plates were rinsed twice with distilled water and the oysters were collected using a razor blade. Dry weight was measured after $48 \mathrm{~h}$ at $60^{\circ} \mathrm{C}$, and organic matter was determined by weight loss after $24 \mathrm{~h}$ at $450^{\circ} \mathrm{C}$ in a muffle furnace. Organic weight content $(\mathrm{OW})$ was expressed as the $\mathrm{OW}$ percentage of the dry weight. 


\section{Light measurements}

Photosynthetically Active Radiation (PAR) was measured using the spherical quantum sensor LI-193SA from LI-COR ${ }^{\circledR}$ Corporation. At the laboratory, light conditions were compared between the glass tank with the microcosms and outside the laboratory building. In situ, light conditions were measured at the depth of the microcosms and at the sea surface.

\section{Statistical analysis}

The first step of our data treatment was to test for significant differences using one-way ANOVAs. For this purpose, the data first needed to be tested for homogeneity of variances and normal distributions. Bartlett's test for homogeneity and the Kolmogorov-Smirnov test for normality were applied. As several variables did not fulfill both conditions, the ANOVA test could not be applied. Therefore, following the statistical procedures given in Sokal and Rohlf (1995), a Kruskal-Wallis test was used to test for significant differences in multiple treatment sets, and when the answer was positive, a Mann-Whitney test was run for pairwise comparisons. Statistical tests were performed using the Statgraphics® Plus v5.1 software.

\section{Results}

\section{Food availability}

On the 11th day of the experiment, our tests show that the new water put in the microcosms, which came from the surface, contained $2.1 \mu \mathrm{g} . \mathrm{L}^{-1}$ of Chl $a$. Chl $a$ in the in situ controls two days later was $1.27 \pm 0.15 \mu \mathrm{g} . \mathrm{L}^{-1}$ (Figure 3) (67\% remaining), showing that there was still Chl $a$ available. 


\section{Oysters in microcosms}

At the beginning of the experiment, oysters were six weeks old. Mean shell dimensions of controls (Table 1), ranged from 0.87 to $1.07 \mathrm{~mm}$ on the first day, and had reached 1.31-1.53 $\mathrm{mm}$ by the end of the experiment, showing a $126 \% \pm 4.1 \%$ (mean \pm Standard Error, (SE)) Ai increase for controls over the 13 day period.

Mortality observed in controls was $19.5 \% \pm 8.1 \%$ (mean \pm SE) after 13 days (Figure 4).

\section{Pesticide effects on oyster spat}

Concentrations detected for Basamaïs ${ }^{\circledR}$ ranged from $58 \%$ to $69 \%$ of the nominal amount added, and from $64 \%$ to $85 \%$ for Opus ${ }^{\circledR}$ (Table 2).

Opus ${ }^{\circledR}$ and Basamaïs ${ }^{\circledR}$ at $10 \mu \mathrm{g} . \mathrm{L}^{-1}$ were tested alone and combined in a mixture containing this concentration of each.

In spite of higher Chl a mean value for basamais treatments (Figure 3), no significant difference among treatment could be demonstrated (Kruskall-Wallis, $\mathrm{p}>0.05$ ). No significant difference in mortality (Figure 4) was detected. Organic weight content values (Figure 5) ranged from $13 \%$ to $20.8 \%$, and no significant differences were detected among the treatments (Kruskall-Wallis, $\mathrm{p}>0.05$ ).

Opus ${ }^{\circledR}$ and Basamaïs ${ }^{\circledR}$ tested alone resulted in $127 \% \pm 3.9 \%$ and $123 \% \pm 4 \%$ spat growth respectively (mean $\pm \mathrm{SE}$ ) (Figure 5), which is close to the control result $(126 \% \pm 4.1 \%)$ and therefore showing no evidence of significant differences between treatments (Mann-Whitney, p>0.05). Nevertheless, with $10 \mu \mathrm{g} \cdot \mathrm{L}^{-1}$ of each of Opus® and Basamaïs ${ }^{\circledR}$ combined, growth was reduced by almost half $(65 \% \pm 3 \%)$. This highly significant reduction in growth (MannWhitney, $\mathrm{p}<0.0001)$ suggests a synergistic effect. 
As size increase was evaluated individually, we were able to draw an area index increase distribution bar chart for the combined Opus and Basamaïs treatment (Figure 6). The shape of the bar chart appears similar to that of the controls, but the distribution is significantly different and exhibits lower values (Kolmogorov-Smirnov, $\mathrm{p}<0.05)$. This result suggests that the combination of these two pesticides impacts oysters by reducing growth of the whole population.

Both pesticides were also tested at the higher concentration of $70 \mu \mathrm{g} . \mathrm{L}^{-1}$ (Figure 7).

Growth of spat exposed to $70 \mu \mathrm{g} . \mathrm{L}^{-1}$ of Basamaïs ${ }^{\circledR}$ was slightly lower than in the controls $(108 \% \pm 4.5 \%)$ (Mann-Whitney, $\mathrm{p}=0.0049)$. A highly significantly lower oyster growth $(49 \%$ $\pm 2 \%$ ) was observed when $70 \mu \mathrm{g} \cdot \mathrm{L}^{-1}$ Opus ${ }^{\circledR}$ was added, which was 2.5 times lower than for the controls $(126 \% \pm 4.1 \%$ ) (Mann-Whitney, $\mathrm{p}<0.0001)$. In the Opus ${ }^{\circledR} 70 \mu \mathrm{g} . \mathrm{L}^{-1}$ treatment, the growth distribution (Figure 8) was significantly different from the controls (KolmogorovSmirnov $\mathrm{p}<0.05)$ and the shape was narrower: no individual growth was greater than $150 \%$, leading to a drastic reduction in median growth.

No significant difference in organic weight was observed among the $70 \mu \mathrm{g} . \mathrm{L}^{-1}$ pesticide treatments and controls (Kruskall-Wallis, p>0.05, Figure 7).

\section{Comparison between in situ controls and indoor bottles.}

As such field microcosm experiments are time consuming and subject to unpredictability of the weather, a simplified protocol was tested where microcosms were maintained in a lab water bath under simulated underwater light conditions.

During this indoor microcosms experiment, no significant difference in mortality could be demonstrated compared with outdoor in situ controls (Mann-Whitney, $\mathrm{p}>0.05$ ): indoor spat 
suffered $32.5 \% \pm 14 \%$ mortality, while in situ control mortality was $19.5 \% \pm 8 \%$. Indoor spat showed growth of $121 \% \pm 5.6 \%$ (Figure 9a), with no evidence of a significant difference with in situ controls $(126 \% \pm 4.1 \%)$ (Mann-Whitney, $\mathrm{p}>0.05)$. No difference was observed in OW content (Mann-Whitney, p>0.05), which was $16 \% \pm 3 \%$ for in situ controls, and $20.8 \% \pm$ $6.6 \%$ for indoor controls (data not shown).

The mean Chl $a$ value (Figure $9 \mathrm{~b})$ observed in laboratory bottles $\left(0.65 \pm 0.12 \mu \mathrm{g} . \mathrm{L}^{-1}\right)$ was significantly lower than the value from in situ control bottles $\left(1.27 \pm 0.15 \mu \mathrm{g} . \mathrm{L}^{-1}\right)$ (MannWhitney, $\mathrm{p}=0.02$ ).

The water temperature at the experimental site was $18^{\circ} \mathrm{C}\left( \pm 1^{\circ} \mathrm{C}\right)$ during the experiment. This temperature was applied in the indoor tank to mimic the outdoor conditions.

For both laboratory and in situ experiments, light intensity was compared between positions close to the microcosms and those outside these light environments. PAR measurements in the laboratory water bath (Table 3) were more than 20 times lower than just outside the lab. Measurements at $6 \mathrm{~m}$ depth underwater were only about 10 times lower than those at water surface. This indicates that indoor bottles received half the mean PAR compared with the in situ field site bottles.

\section{Discussion}

\section{Microcosms}

The in situ microcosms used in the present study were exposed to natural underwater temperature and light conditions. Natural seawater phytoplankton was the unique nutrient source for these oyster spat. Following preliminary experiments, it was decided to totally renew the content of the bottles every other day in order to supply a sufficient amount of phytoplankton. For practical reasons, sea water for renewal was collected in the surface 50 
$\mathrm{cm}$. The mixed layer of ocean surface waters is in fact estimated to fluctuate from several meters depth in very calm conditions to 100 meters or more in strong wind and wave conditions (Bendtsen et al, 2006; Nilsen and Falck, 2006), meaning that the water added to our microcosms can be considered as representative of coastal surface waters surrounding natural oyster populations. An air overlay was also included in our microcosms to simulate gas exchanges occurring in free seawater (de la Broise and Palenik, 2007). By measuring Chl $a$ at renewal and after 2 days in the microcosms, we showed that the concentration had only decreased from $2.1 \mu \mathrm{g} . \mathrm{L}^{-1}$ to $1.27 \mu \mathrm{g} . \mathrm{L}^{-1}$. This suggests that the renewal rate we used was sufficient to avoid starvation. Brown and MacCausland (2000) showed that food supply, temperature and salinity were the main factors affecting oyster spat growth and Ponis et al. (2003a) reported a shell length increment of about $11 \%$ for starved $C$. gigas juveniles in a four-week feeding trial starting with an initial shell length of $1400 \mu \mathrm{m}$. In the present experiment, the oysters started at an average size of $1050 \mu \mathrm{m}$ and showed a $44 \%$ length increase within 13 days (Table 1). This result corresponds to a length increase rate 8 times higher than that observed by Ponis et al (2003a), again suggesting that food had not become limiting in our experiment.

Shellfish growth is usually based either on weight (Child and Laing, 1998; Laing and Chang, 1998; Collet et al., 1999; Brown and Mc Causland, 2000; Brown and Robert, 2002), volumetric analysis (Brown and Mc Causland, 2000; Brown and Robert, 2002), or length measurement of just one side of the oyster (Collet et al., 1999; Brown and Robert, 2002; Ponis et al., 2003a; Ponis et al., 2003b). However, at this early spat stage, oysters tend to grow unevenly between the axes, and the measurement of surface area is more representative of their development. Moreover, for studies involving oyster larvae, size measurements are usually made on different individuals sampled at the beginning and at the end of experiments. In our case, the fact that oysters had settled on the plates, and the use of photographs, allowed 
us to measure the same specimens at different points in time. Thus, we could obtain the individual growth distributions for each treatment, which described the impacts on the population more precisely.

This approach is therefore particularly useful for estimating whether a toxicant acts homogeneously on the whole population.

As larval settlement was carried out at two different locations, this increased the diversity in morphological and physiological states of the oysters and therefore improved the relevance of the results. On the other hand, this undoubtedly induced more variability in the data collected, although it was still possible to detect highly significant differences in growth between treatments.

Considering the early stage of development, their high density on the plates, and possible effects of the change in feeding conditions from hatchery to microcosm, the mortality of control spat was relatively low. Together with the $126 \%$ growth observed within 13 days, these data illustrate that the in situ immersed microcosms tested here allowed oyster spat to be maintained successfully for 2 weeks in natural temperature, light, and nutrient conditions in an enclosed environment. This microcosm system is thus relevant for experiments on oyster spat in these environmental conditions, and thus provides a method for running toxicity tests. 


\section{Pesticide effects on oyster spat}

Pesticide concentrations detected in microcosm samples were lower than the nominal amounts added to the bottles. Similar results were reported by Damiens et al. (2004), who observed an average loss of 55\% for carbofuran, and less for malathion. Bouilly et al. (2004) recorded atrazine concentrations in agreement with those expected just after pesticide addition, but a $20 \%$ decrease after $24 \mathrm{~h}$. Such results could be explained by pesticide adsorption to the bottle/container walls and/or on the organic matter of seawater.

In order to assess pesticide toxicity on oyster spat, three parameters were analyzed: mortality, organic weight content and growth. Mortality and OW content variables were not affected or not sensitive enough to show differences between treatments, whereas growth measurements revealed highly significant differences. The very low p-values obtained through the different tests $(\mathrm{p}<0.0001)$ indicate that similar results would have been obtained with a much smaller number or measurements. Such analyses could probably be run successfully with either fewer replicates or fewer than 50 oysters measured per plate.

While growth (measured as area index increase) seems to represent a better parameter for toxicity assessment than mortality and OW content, other more precise analyses could also be performed, such as measurement of biomarker levels (acetylcholinesterase (AchE) activity, thiobarbituric acid reactive substances (TBARS), glutathione $S$-transferase (GST) and catalase (CAT) activities) as used by Damiens et al. (2004) and Quiniou et al. (2007). However, shell area index increase is both a simple and reliable method.

Pesticides at a concentration of $10 \mu \mathrm{g} . \mathrm{L}^{-1}$ did not show any significant effect on spat growth when tested alone. However, the combination of $10 \mu \mathrm{g} . \mathrm{L}^{-1}$ of each of Opus and Basamaïs caused a dramatic reduction in growth after a 13-day exposure. As no significant reduction 
was noticed for Chl $a$ in this combined treatment, the hypothesis of the reduction of feed availability acting negatively on oyster growth can be rejected. The combined pesticide effect could be due either to a specific reduction of some distinctive phytoplankton species important for oyster growth, or to a direct effect of pesticides on oyster physiology. Cedergreen et al. (2006) also noticed synergistic effects of mixed esfenvalerate (insecticide) and prochloraz (fungicide) on Daphnia magna: the esfenvalerate concentration that was required to immobilize $50 \%$ of the daphnia was reduced from 3 to less than $0.5 \mu \mathrm{g} . \mathrm{L}^{-1}$ when prochloraz was added. Such results highlight the need to further investigate the toxicity threshold of such contaminant combinations in natural conditions.

When higher concentrations (70 $\left.\mu \mathrm{g} . \mathrm{L}^{-1}\right)$ were tested, Basamaïs induced a slight growth reduction but Opus strongly reduced growth. This strong negative effect impacted a large proportion of the oyster population, as can be seen on the distribution bar chart (Figure 8). Further studies should be carried out to better characterize mechanisms involved in this Opus toxicity.

Pesticide concentrations encountered in estuarine areas are usually below $1 \mu \mathrm{g} . \mathrm{L}^{-1}$ (Lehotey et al., 1999; Steen et al., 2001; Oros et al., 2003). The $10 \mu \mathrm{g} . \mathrm{L}^{-1}$ values tested here could represent an extreme environmental peak value in such areas. Our result illustrates that pesticide combination, which often occurs in natural environment due to runoff, could possibly seriously damage oyster spat growth in natural areas such as estuaries, and also in hatcheries located in estuarine areas. This suggests that pesticides should not be considered as isolated molecules, but as parts of mixtures involved in complex chemical and biological interactions. 


\section{Comparison between in situ controls and indoor bottles.}

As in situ experiments are time-consuming and subject to unpredictable weather, we evaluated a laboratory protocol to simulate the natural environment. A critical element of such indoor experiments, which involve phytoplankton, is the light conditions: it is difficult to mimic in situ light spectra and intensity fluctuations. Using natural light through specific filters, the microcosms could experience diurnal intensity fluctuations and also the unpredictable fluctuations due to clouds. PAR reduction in the laboratory experiment compared with outside, was greater than for the in situ reduction between PAR at the depth of the microcosms and the surface. Outdoors, the in situ bottles received double the PAR on average compared with the indoor bottles. This difference in light intensity could explain the differences detected for $\mathrm{Chl} a$ concentration between laboratory $\left(0.65 \mu \mathrm{g} . \mathrm{L}^{-1}\right)$ and in situ $(1.27$ $\mu \mathrm{g} . \mathrm{L}^{-1}$ ) bottles on the last day of the experiment. Indeed, it should be noted that the phytoplankton concentration in bottles is not only depleted, due to oyster filtration and small grazers, but also augmented by photosynthetic growth that is highly light-dependant (de la Broise and Palenik 2007). The lab microcosms system could be improved by increasing PAR reaching the bottles. However, as the lab tank was located just behind a south-facing window, it appears difficult to further increase light intensity. Another possibility would be to increase the water renewal rate up to a daily frequency.

In spite of this difference between indoor and outdoor conditions, no significant difference could be observed in growth, mortality or OW content of spat. These results suggest that our indoor microcosm system allows experiments on oyster spat, as an alternative to the outdoor microcosm system. 


\section{Conclusion}

The enclosed microcosm system presented here, with air overlay, total medium renewal, and exposure to natural temperature and light conditions, led to acceptable oyster spat survival and high growth throughout a 13 day-experiment, in in situ field conditions as well as in the laboratory. Numerous microcosms can be easily handled simultaneously, which can allow the simultaneous testing of different molecules and concentrations with adequate replication for an objective statistical treatment. Such closed systems could probably be used for ecotoxicity tests with other mollusks.

The analysis of the shell area index increase revealed a synergistic effect of Basamaïs and Opus when present together at $10 \mu \mathrm{g} . \mathrm{L}^{-1}$, a value that simulates a peak environmental concentration in estuarine conditions. This last result illustrates the high sensitivity of $C$. gigas spat to pesticides, and thus the ecological relevance of this developmental stage for toxicity assessment. It also highlights the need for further studies testing sensitivity threshold and dealing with the mechanisms involved in synergistic effects.

\section{Acknowledgements}

We wish to thank the "Ministère de l'Ecologie et du Développement Durable", and the "Région Bretagne", who financially supported this research. We thank the Capitainerie de Beg-Meil, city of Fouesnant and Patrick Le Coz for their technical assistance; Xavier Caisey, Pierre Mollo and Christian Mingant who provided assistance with spat settlement; Hansy Haberkorn, Gaël Durand, Geneviève Arzul, Louis Coroller and Jacques Baron. 


\section{References}

Aminot A, Kérouel R (2004) Hydrologie des écosystèmes marins. Paramètres et analyses. Editions Ifremer, Plouzané, France pp 172-194

Amiard-Triquet C, Altmann S, Amiard JC, Ballan-Dufrançais C, Baumard P, Budzinski H, Crouzet C, Garrigues P, His E, Jeantet AY, Menasria R, Mora P, Mouneyrac C, Narbonne JF, Pavillon JF (1998) Fate and effects of micropollutants in the Gironde estuary, France: a multidisciplinary approach. Hydrobiologia 373-374(0): 259-279

Arnold GL, Luckenbach MW, Unger MA (2004) Runoff from tomato cultivation in the estuarine environment: biological effects of farm management practices. J Exp Mar Biol Ecol 298(2): 323-346

Auffret M, Oubella R (1997) Hemocyte aggregation in the oyster Crassostrea gigas: In vitro measurement and experimental modulation by xenobiotics. Comp Biochem Physiol 118A (3): 705-712

Avery EL, Dunstan RH (1996) The Detection of Pollutant Impact in Marine Environments: Condition Index, Oxidative DNA Damage, and Their Associations with Metal Bioaccumulation in the Sydney Rock Oyster Saccostrea commercialis. Arch Environ Contam Toxicol 31(2): 192-198

Banks KE, Turner PK, Wood SH, Matthews C (2005) Increased toxicity to Ceriodaphnia dubia in mixtures of atrazine and diazinon at environmentally realistic concentrations. Ecotox Environ Safe 60(1): 28-36

Bendtsen J, Gustafsson KE, Petersen JK (2006) Modelling vertical mixing in the surface boundary layer using artificial age tracers. Journal of marine systems $60: 115-128$

Bolton-Warberg M, Coen LD, Weinstein JE (2007) Acute Toxicity and Acetylcholinesterase Inhibition in Grass Shrimp (Palaemonetes pugio) and Oysters (Crassostrea virginica) 
Exposed to the Organophosphate Dichlorvos: Laboratory and Field Studies. Arch Environ Contam Toxicol 52(2): 207-216

Bouilly K, McCombie H, Leitão A, Lapègue S (2004) Persistence of atrazine impact on aneuploidy in Pacific oysters, Crassostrea gigas. Mar Biol 145(4): 699-705

Bouilly K, Bonnard M, Gagnaire B, Renault T, Lapègue S (2007) Impact of Diuron on Aneuploidy and Hemocyte Parameters in Pacific Oyster, Crassostrea gigas. Arch. Environ Contam Toxicol 52(1): 58-63

Brown MR, McCausland MA (2000) Increasing the growth of juvenile Pacific oysters Crassostrea gigas by supplementary feeding with microalgal and dried diets. Aquac Res 31(8-9): 671-682

Brown M, Robert R (2002) Preparation and assessment of microalgal concentrates as feeds for larval and juvenile Pacific oyster (Crassostrea gigas). Aquaculture 207(3-4): 289309

Cedergreen N, Kamper A, Streibig JC (2006) Is prochloraz a potent synergist across aquatic species? A study on bacteria, daphnia, algae and higher plants. Aquat Toxicol 78(3): $243-252$

Child AR, Laing I (1998) Comparative low temperature tolerance of small juvenile European, Ostrea edulis L., and Pacific oysters, Crassostrea gigas Thunberg. Aquac Res 29:103113

Christl TJ, Pennington P, DeLorenzo M, Karnaky KJ, Scott GI (2004) Effect of Multiple Atrazine Exposure Profiles on Hemocyte DNA Integrity in the Eastern Oyster (Crassostrea virginica). Bull. Environ Contam Toxicol 73(2): 404-410

Clara Reboucas do Amaral M, de Freitas Rebelo M, Paulo Machado Torres J, Christian Pfeiffer W (2005) Bioaccumulation and depuration of $\mathrm{Zn}$ and $\mathrm{Cd}$ in mangrove oysters 
(Crassostrea rhizophorae, Guilding, 1828) transplanted to and from a contaminated tropical coastal lagoon. Mar Environ Res 59(4): 277-285

Collet B, Boudry P, Thebault A, Heurtebise S, Morand B, Gerard A (1999) Relationship between pre- and post-metamorphic growth in the Pacific oyster Crassostrea gigas (Thunberg). Aquaculture 175(3-4): 215-226

da Cruz ACS, Couto BC, Nascimento IA, Pereira SA, Leite MBNL, Bertoletti E, Zagatto P (2007) Estimation of the critical effect level for pollution prevention based on oyster embryonic development toxicity test: The search for reliability. Environ Int 33 (4) $589-595$

Damiens G, His E, Gnassia-Barelli M, Quiniou F, Romeo M, (2004) Evaluation of biomarkers in oyster larvae in natural and polluted conditions. Comp Biochem Physiol 138C (2): $121-128$

de la Broise D, Palenik B (2007) Immersed in situ microcosms: A tool for the assessment of pollution impact on phytoplankton. J Exp Mar Biol Ecol 341(2): 274-281

Fernandez-Alba AR, Guil LH, Lopez GD, Chisti Y (2001) Toxicity of pesticides in wastewater: a comparative assessment of rapid bioassays. Anal. Chim. Acta 426(2): 289-301

Gagnaire B, Thomas-Guyon H, Renault T, (2004) In vitro effects of cadmium and mercury on Pacific oyster, Crassostrea gigas (Thunberg), haemocytes. Fish Shellfish Immunol 16(4): 501-512

Geffard O, His E, Budzinski H, Seaman M, Garrigues P (2001) Qualité biologique de l'eau de mer évaluée in situ par le test embryo-larvaire de Crassostrea gigas et Mytilus galloprovincialis. In situ monitoring of sea water quality with the embryo-larval bioassay of Crassostrea gigas and Mytilus galloprovincialis. Comptes Rendus de l'Academie des Sciences - Series III - Sciences de la Vie. 324(12): 1149-1155 
Geffard O, Geffard A, His E, Budzinski H (2003) Assessment of the bioavailability and toxicity of sediment-associated polycyclic aromatic hydrocarbons and heavy metals applied to Crassostrea gigas embryos and larvae. Mar Pollut Bull 46(4): 481-490

Geffard O, His E, Budzinski H, Chiffoleau JF, Coynel A, Etcheber H (2004) Effects of storage method and duration on the toxicity of marine sediments to embryos of Crassostrea gigas oysters. Environ. Pollut. 129(3): 457-465

Girard S, Perez-Agundez JA, Miossec L, Czerwinski N (2005) Recensement de la conchyliculture 2001. Cahiers (conchyliculture) $n^{\circ} 1$. Les productions Agreste, Paris.

His E, Beiras R, Quiniou F, Parr ACS, Smith MJ, Cowling MJ, Hodgkiess T (1996) The nontoxic effects of a novel antifouling material on oyster culture. Water Res 30(11): 28222825

His E, Budzinski H, Geffard O, Beiras R (1997) Action d'un sédiment pollué par les hydrocarbures sur la métamorphose de l'huître japonaise, Crassostrea gigas (Thunberg). Effects of a hydrocarbon-polluted sediment on Crassostrea gigas (Thunberg) metamorphosis. Comptes Rendus de l'Academie des Sciences - Series III Sciences de la Vie. 320(10): 797-803

His E, Heyvang I, Geffard O, de Montaudouin X (1999) A comparison between oyster (Crassostrea gigas) and sea urchin (Paracentrotus lividus) larval bioassays for toxicological studies. Water Res 33(7): 1706-1718

Laing I, Chang RM (1998) Hatchery cultivation of Pacific oyster juveniles using algae produced in outdoor bloom-tanks. Aquac Int 6(4): 303-315

Lehotey SJ, Harman-Fetcho JA, McConnell LL (1998) Agricultural pesticide residues in oysters and water from two Chesapeake bay tributaries. Mar Pollut Bull 37(1-2): 3234 
Li Q, Osada M, Takahashi K, Matsutani T, Mori K (1997) Accumulation and Depuration of Tributyltin Oxide and Its Effect on the Fertilization and Embryonic Development in the Pacific Oyster, Crassostrea gigas. Bull Environ Contam Toxicol 58(3): 489-496

Losso C, Novelli AA, Picone M, Marchetto D, Pantani C, Ghetti PF, Ghirardini AV (2007) Potential role of sulfide and ammonia as confounding factors in elutriate toxicity bioassays with early life stages of sea urchins and bivalves. Ecotox Environ Safe 66(2): $252-257$

Lyons BP, Pascoe CK, McFadzen IRB (2002) Phototoxicity of pyrene and benzo[a]pyrene to embryo-larval stages of the pacific oyster Crassostrea gigas. Mar Environ Res 54(35): $627-631$

Nice HE, Thorndyke MC, Morritt D, Steele S, Crane M (2000) Development of Crassostrea gigas Larvae is Affected by 4-nonylphenol. Mar Pollut Bull 40(6): 491-496

Nilsen JEO, Falck E (2006) Variations of mixed layer properties in the Norwegian sea for the period 1948-1999. Prog Oceanogr 70: 58-90

Oliver LM, Fisher WS, Winstead JT, Hemmer BL, Long ER (2001) Relationships between tissue contaminants and defense-related characteristics of oysters (Crassostrea virginica) from five Florida bays. Aquat Toxicol 55(3-4): 203-222

Oros DR, Jarman WM, Lowe T, David N, Lowe S, Davis JA (2003) Surveillance for previously unmonitored organic contaminants in the San Francisco estuary. Mar Pollut Bull 46: 1102-1110

Paixão JF, Nascimento IA, Pereira SA, Leite MBL, Carvalho GC, Silveira Jr JSC, Reboucas M, Matias GRA, Rodrigues ILP (2007) Estimating the gasoline components and formulations toxicity to microalgae (Tetraselmis chuii) and oyster (Crassostrea rhizophorae) embryos: An approach to minimize environmental pollution risk. Environ. Res. 103(3): 365-374 
Ponis E, Robert R, Parisi G (2003a) Nutritional value of fresh and concentrated algal diets for larval and juvenile Pacific oysters (Crassostrea gigas). Aquaculture 221(1-4): 491505.

Ponis E, Robert R, Parisi G, Tredici M (2003b) Assessment of the performance of Pacific oyster (Crassostrea gigas) larvae fed with fresh and preserved Pavlova lutheri concentrates. Aquac. Int. 11(1): 69-79

Quiniou F, Damiens G, Gnassia-Barelli M, Geffard A, Mouneyrac C, Budzinski H, Romeo M (2007) Marine water quality assessment using transplanted oyster larvae. Environ Int 33(1): $27-33$

Riedel GF, Valette-Silver N (2002) Differences in the bioaccumulation of arsenic by oysters from Southeast coastal US and Chesapeake Bay: environmental versus genetic control. Chemosphere 49(1): 27-37

Sokal RR and Rohlf FJ (1995) Biometry: the principles and practice of statistics in biological research. 3rd edition. W. H. Freeman and Co., New York.

Steen RJCA, van der Vart J, Hiep M, Van Hattum B, Cofino WP, Brinkman UAT (2001) Gross fluxes and estuarine behaviour of pesticides in the Scheldt Estuary (1995-1997) Environ. Pollut.115:65-79

Tanguy A, Boutet I, Laroche J, Moraga D (2005) Molecular identification and expression study of differentially regulated genes in the Pacific oyster Crassostrea gigas in response to pesticide exposure. FEBS J. 272(2): 390-403

Wintermyer ML, Cooper KR (2007) The development of an aquatic bivalve model: Evaluating the toxic effects on gametogenesis following 2,3,7,8-tetrachlorodibenzo-pdioxin (2,3,7,8-TCDD) exposure in the eastern oyster (Crassostrea virginica). Aquat Toxicol 81(1): 10-26 
Figure 1. Scheme of the microcosm

a: PVC plate; b: spat; c: air overlay; d: $200 \mu \mathrm{m}$ filtered seawater.

Figure 2. Partial view of a control plate on the first and last days of the experiment.

Figure 3. Chlorophyll $a$ concentration (mean \pm S.E., $\mu$ g.L $\mathrm{L}^{-1}$ ) in bottles (six replicates) on day 13:

C: controls, B. 10: Basamaïs ${ }^{\circledR} 10 \mu \mathrm{g} . \mathrm{L}^{-1}$, B. 70: Basamaïs ${ }^{\circledR} 70 \mu \mathrm{g} . \mathrm{L}^{-1}$, O. 10: Opus ${ }^{\circledR} 10 \mu \mathrm{g} . \mathrm{L}^{-}$

${ }^{1}$, O. 70: Opus ${ }^{\circledR} 70 \mu \mathrm{g} \cdot \mathrm{L}^{-1}, \mathrm{O} 10$ + B10: Opus ${ }^{\circledR} 10 \mu \mathrm{g} \cdot \mathrm{L}^{-1}+$ Basamaïs ${ }^{\circledR} 10 \mu \mathrm{g} \cdot \mathrm{L}^{-1}$.

Figure 4. Oyster spat mortality (mean \pm SE) during the experiment (six replicates)

C: controls, O. 10: Opus $\AA^{\circledR} 10 \mu \mathrm{g} \cdot \mathrm{L}^{-1}$, B. 10: Basamaïs ${ }^{\circledR} 10 \mu \mathrm{g} \cdot \mathrm{L}^{-1}, \mathrm{O} 10+$ B10: Opus ${ }^{\circledR} 10$ $\mu \mathrm{g} \cdot \mathrm{L}^{-1}+$ Basamaïs ${ }^{\circledR} 10 \mu \mathrm{g} \cdot \mathrm{L}^{-1}$, O. 70 : Opus ${ }^{\circledR} 70 \mu \mathrm{g} \cdot \mathrm{L}^{-1}$, B. 70 : Basamaïs ${ }^{\circledR} 70 \mu \mathrm{g} \cdot \mathrm{L}^{-1}$.

Figure 5. Oyster spat shell area index increase (mean \pm SE, six replicates) and organic weight content $(\mathrm{OW})($ mean $\pm \mathrm{SE})$ after $10 \mu \mathrm{g} . \mathrm{L}^{-1}$ pesticide contamination:

C: controls, O. 10: Opus® $10 \mu \mathrm{g} . \mathrm{L}^{-1}$, B. 10: Basamaïs ${ }^{\circledR} 10 \mu \mathrm{g} \cdot \mathrm{L}^{-1}, \mathrm{O} 10$ + B10: Opus ${ }^{\circledR} 10$ $\mu \mathrm{g} . \mathrm{L}^{-1}+$ Basamaïs $\left.{ }^{\circledR} 10 \mu \mathrm{g} \cdot \mathrm{L}^{-1} . \mathrm{(}^{*}\right)$ indicates a significant difference compared with the control $(\mathrm{p}<0.0001)$, and $\mathrm{N}$ is the number of oysters measured for each treatment.

Figure 6. Comparison of area index increase distributions established for controls and Opus® $10 \mu \mathrm{g} . \mathrm{L}^{-1}+$ Basamaïs ${ }^{\circledR} 10 \mu \mathrm{g} . \mathrm{L}^{-1}$ treatment.

Figure 7. Oyster spat area index increase $($ mean \pm SE) and $\mathrm{OW}$ content (mean \pm SE) after 70 $\mu \mathrm{g} . \mathrm{L}^{-1}$ pesticide treatments (six replicates) 
C: controls, B. 70: Basamaïs ${ }^{\circledR} 70 \mu \mathrm{g} \cdot \mathrm{L}^{-1}$, O. 70 : Opus ${ }^{\circledR} 70 \mu \mathrm{g} \cdot \mathrm{L}^{-1} \cdot(*)$ indicates a significant difference compared with controls $(\mathrm{p}<0.0001)$, and $\mathrm{N}$ is the number of oysters measured for each treatment.

Figure 8. Comparison of area index increase distribution for controls and Opus ${ }^{\circledR} 70 \mu$ g.L- ${ }^{1}$ treatment.

Figure 9a. Oyster area index increase (mean \pm SE) and mortality (mean \pm SE) for spat in outdoor (six replicates) and indoor (four replicates) controls.

Figure 9b. Chlorophyll $a$ concentration $\left(\mu \mathrm{g} . \mathrm{L}^{-1}\right)$ in bottles on last day of the experiment (mean $\pm \mathrm{SE}$ ) for outdoor control (six replicates) and indoor control (four replicates). $(*)$ indicates significant difference compared with controls $(\mathrm{p}<0.05)$. 
Table 1. Shell perpendicular lengths (1 and L) and area index (Ai) (mean \pm SE), of oysters on control plates on the first and last days of the experiment (values are means of 290 oysters on six plates).

Table 2. Pesticide concentration added and detected in microcosms and sea water. ND : not detected $(<0.005 \mu \mathrm{g} / \mathrm{L})$. Basamaïs concentration in $\mu \mathrm{g} . \mathrm{L}^{-1}$ bentazone, Opus concentration in $\mu \mathrm{g} . \mathrm{L}^{-1}$ epoxiconazole.

Table 3. PAR (Photosynthetic Active Radiations) ratio measured in sunny and cloudy weather conditions. Ratios were calculated: 1 . between PAR measurements taken outside the laboratory and within the glass tank inside the laboratory, and 2 . between the water surface and $6 \mathrm{~m}$ depth at the field site. 
Figure 2

Figure 2

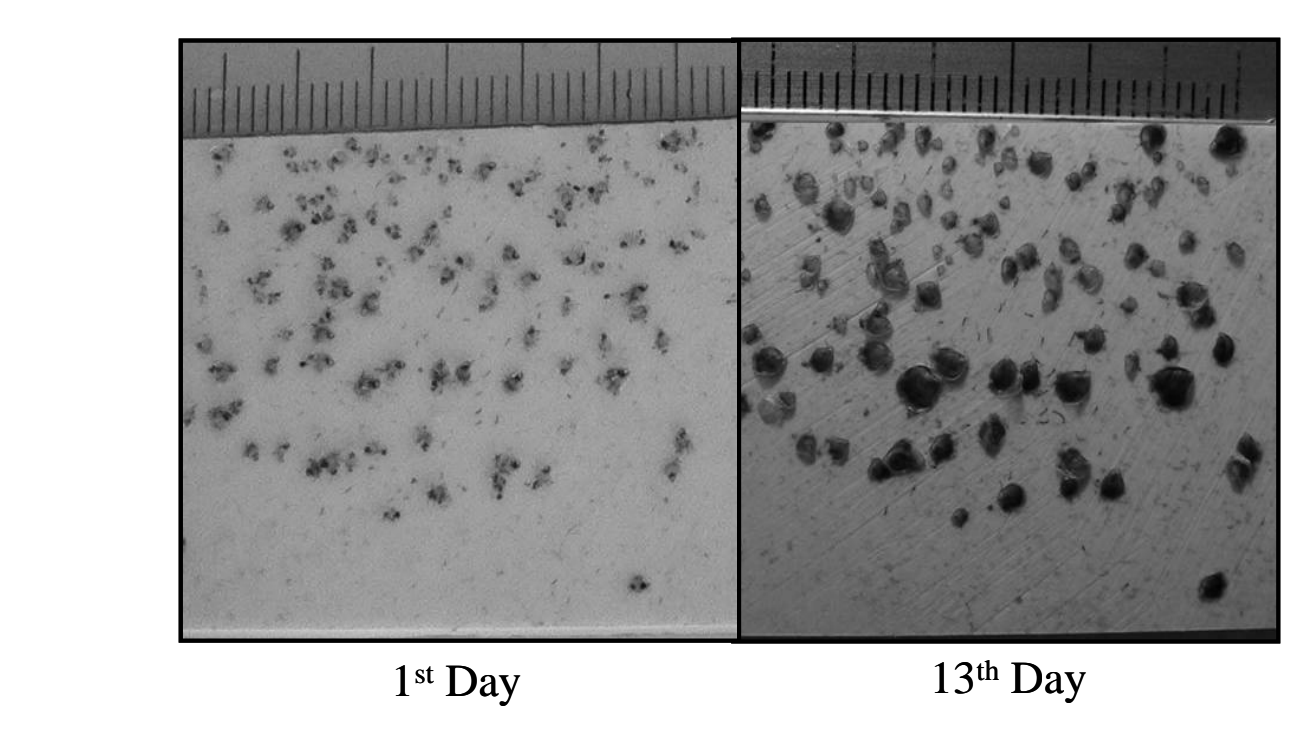

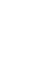


Figure 3

Figure 3

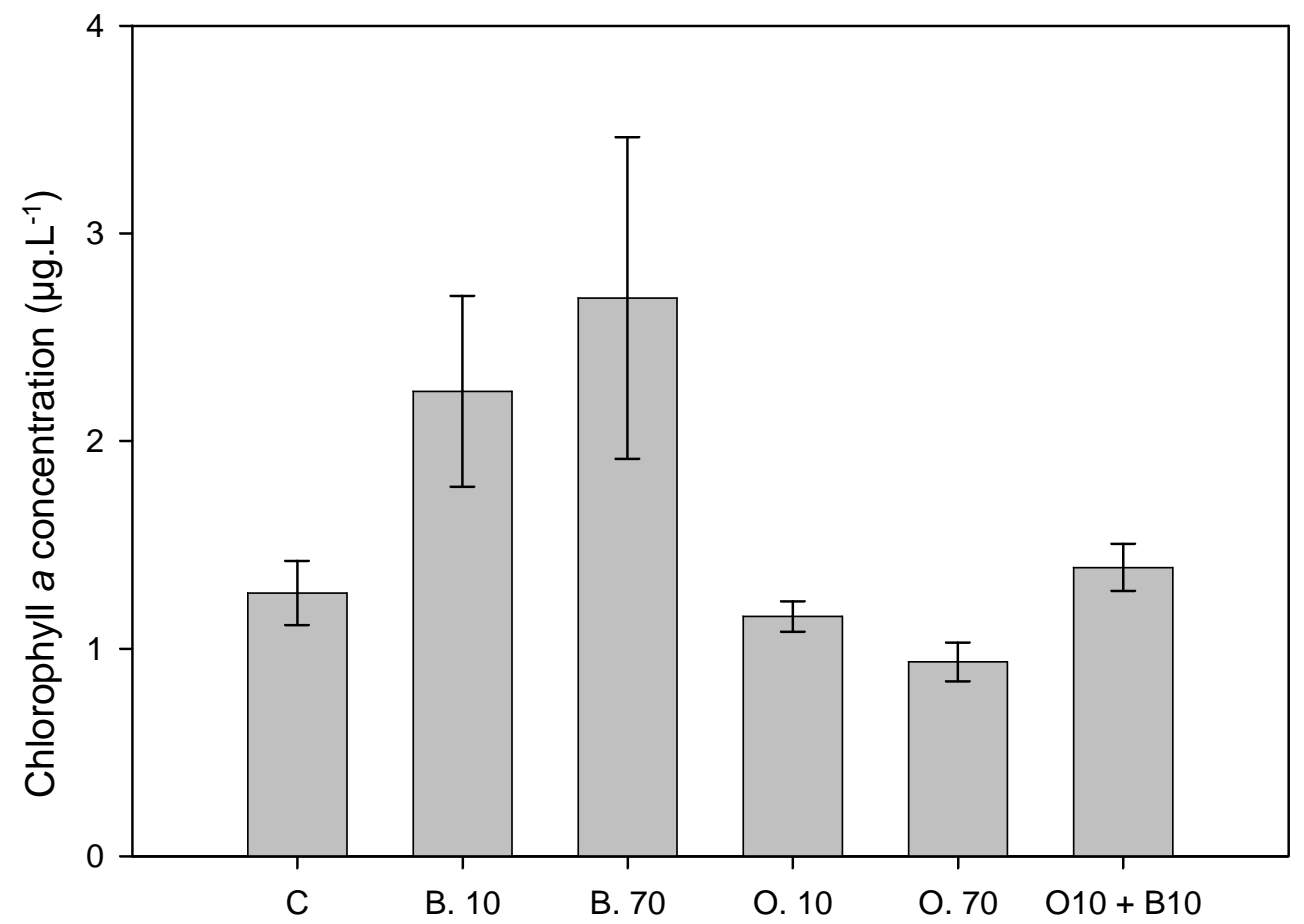


Figure 4

Figure 4

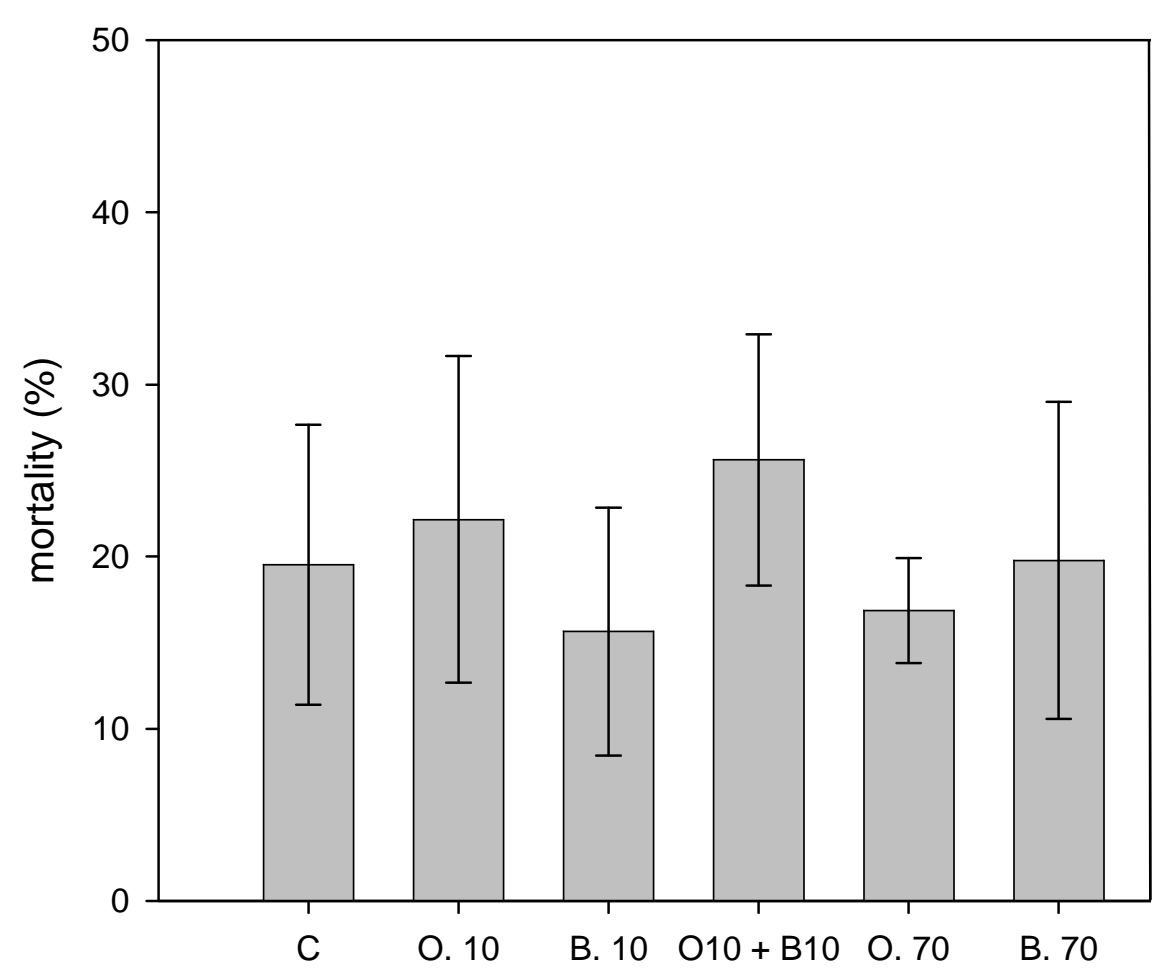


Figure 5

Figure 5

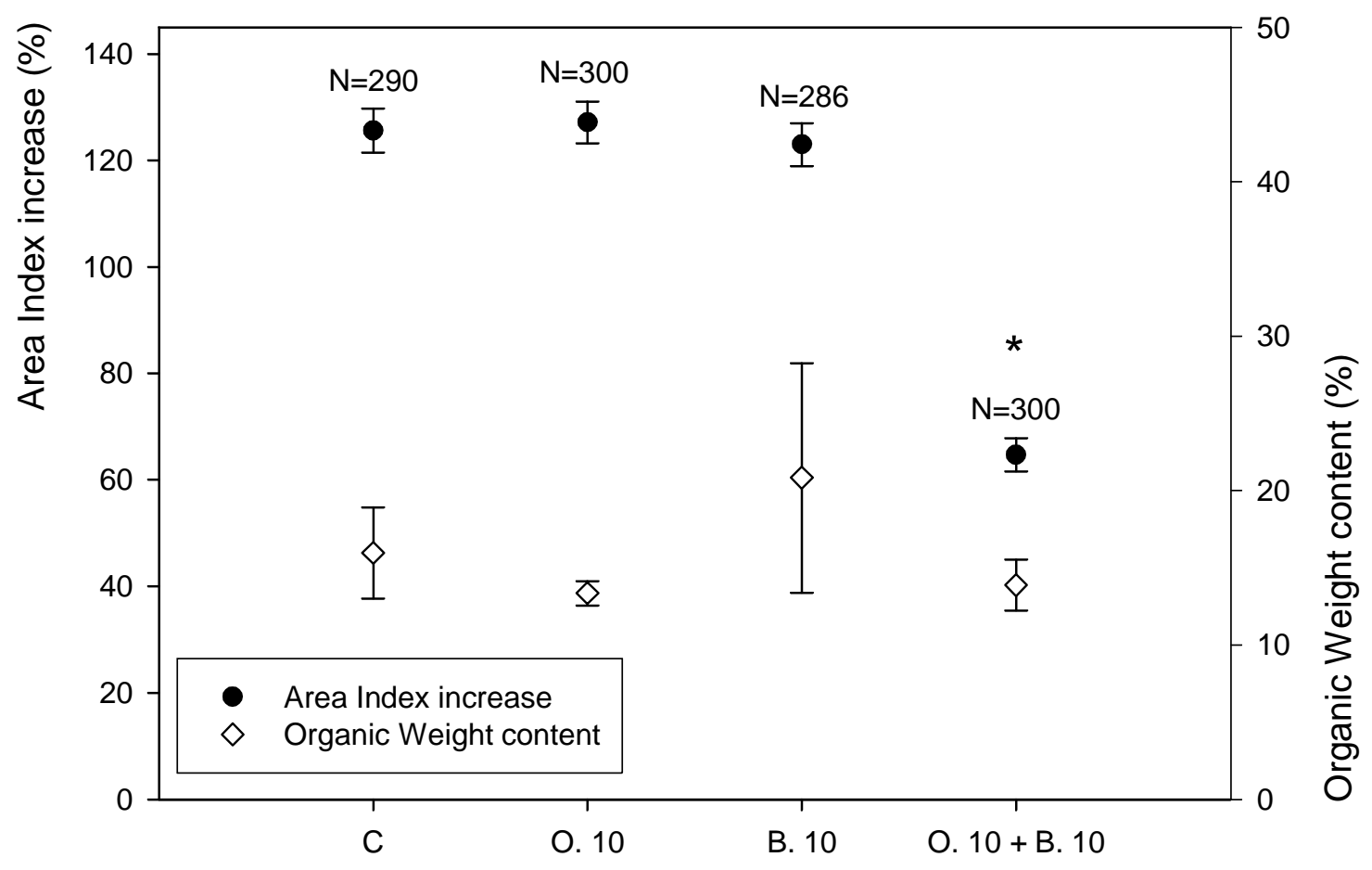


Figure 6

\section{Figure 6}

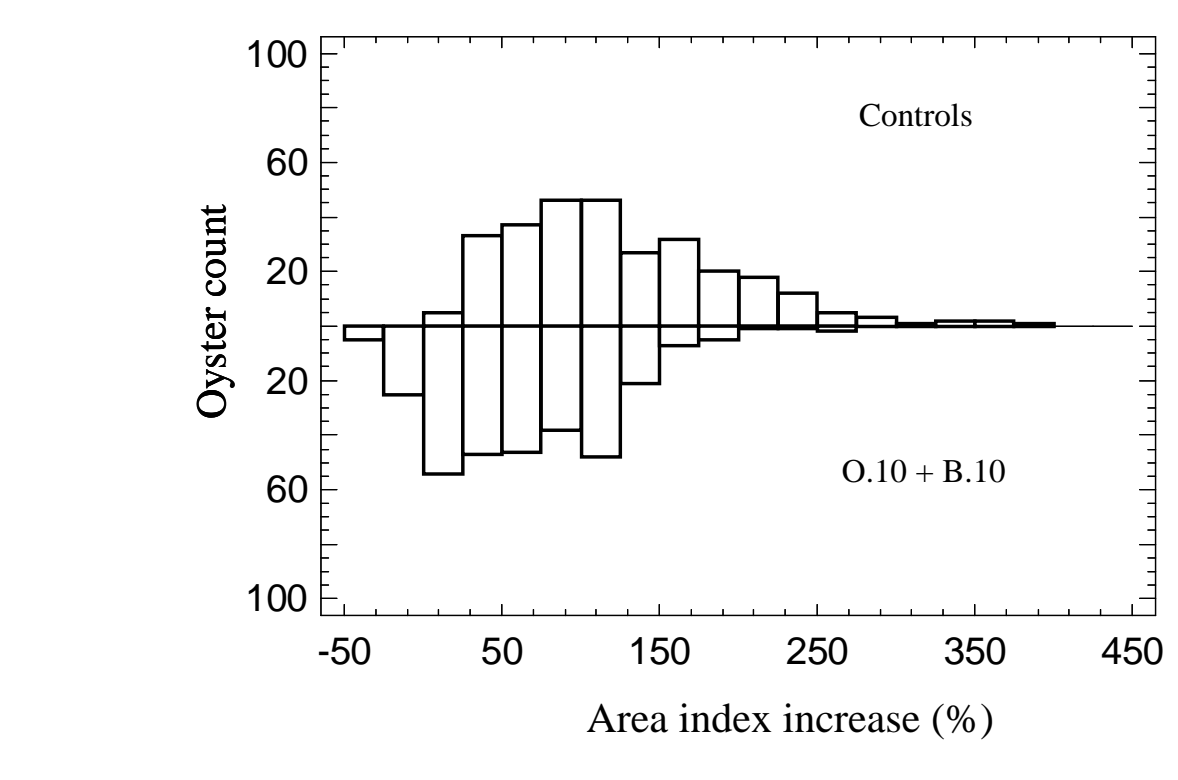

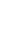

Figure 6 
Figure 8

\section{Figure 8}

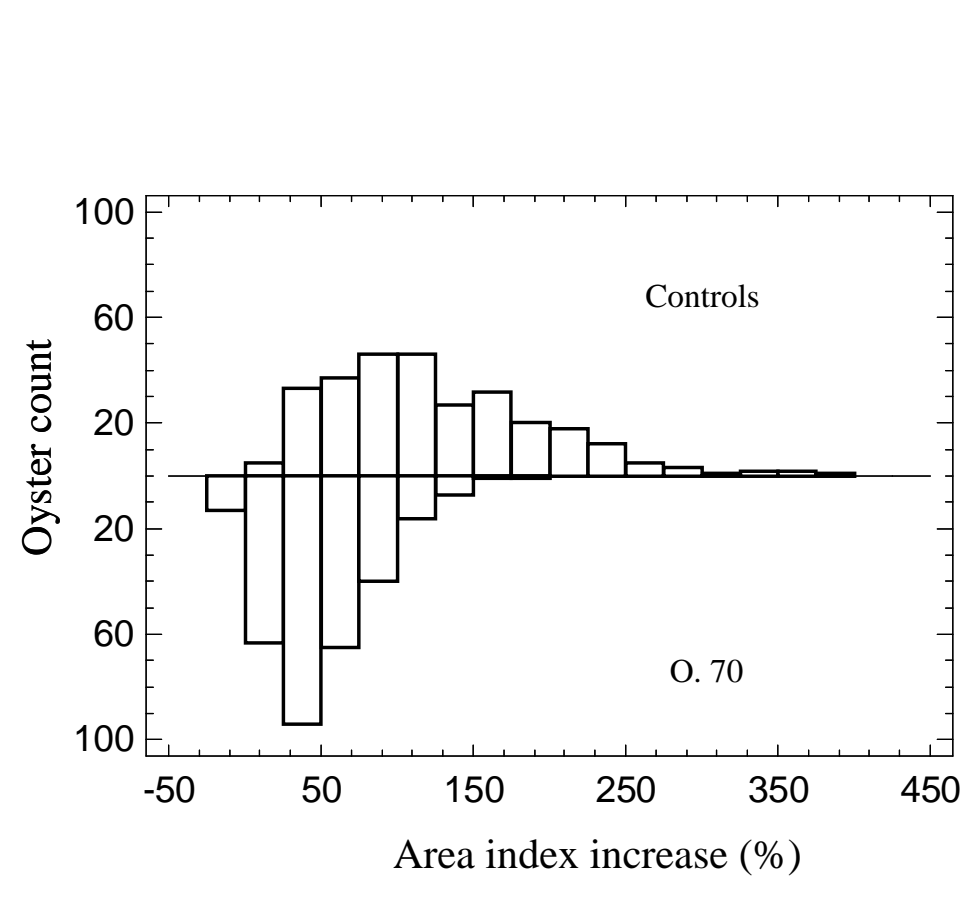

\section{8}


Figure 9a

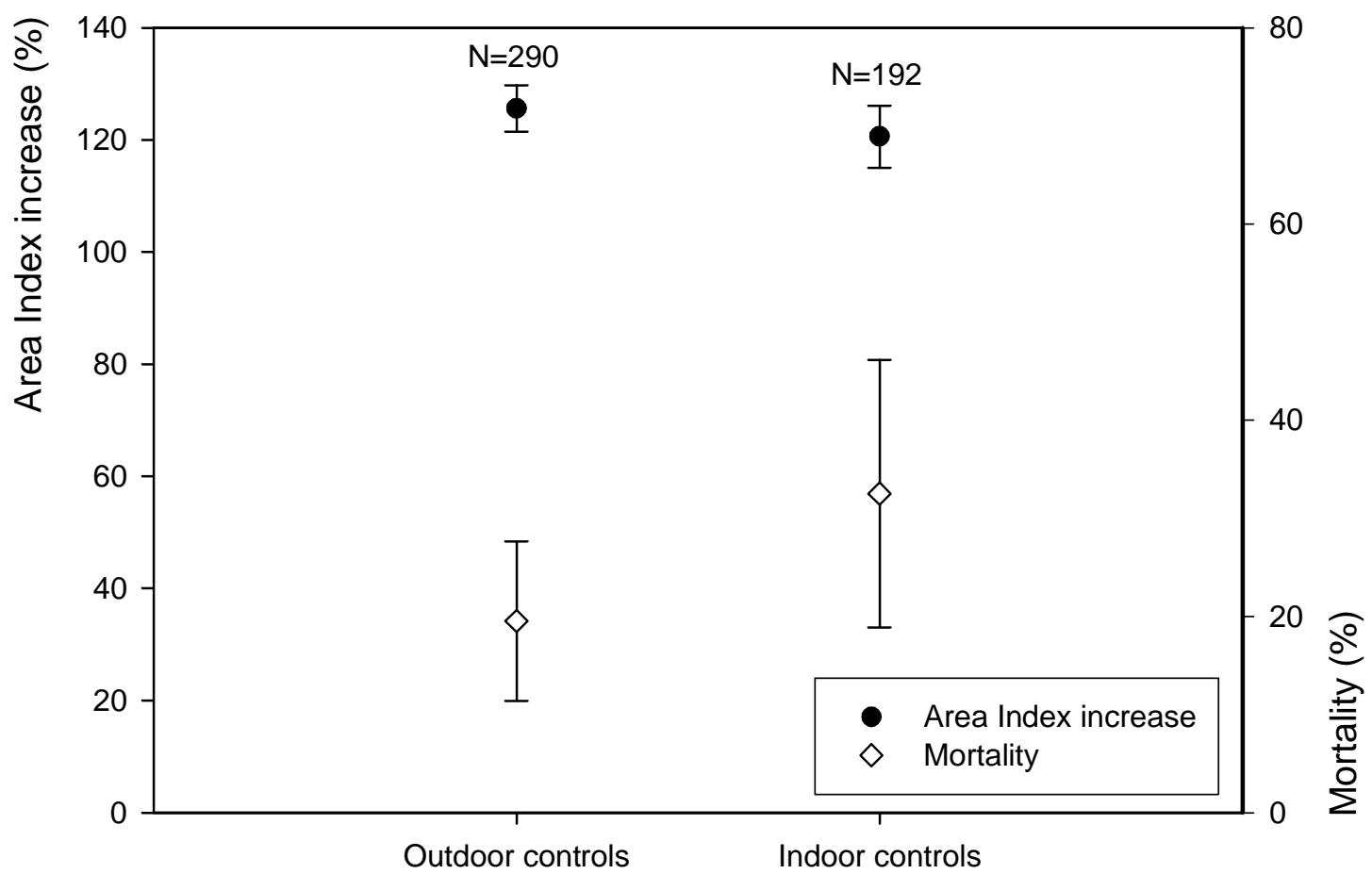

Figure $9 b$

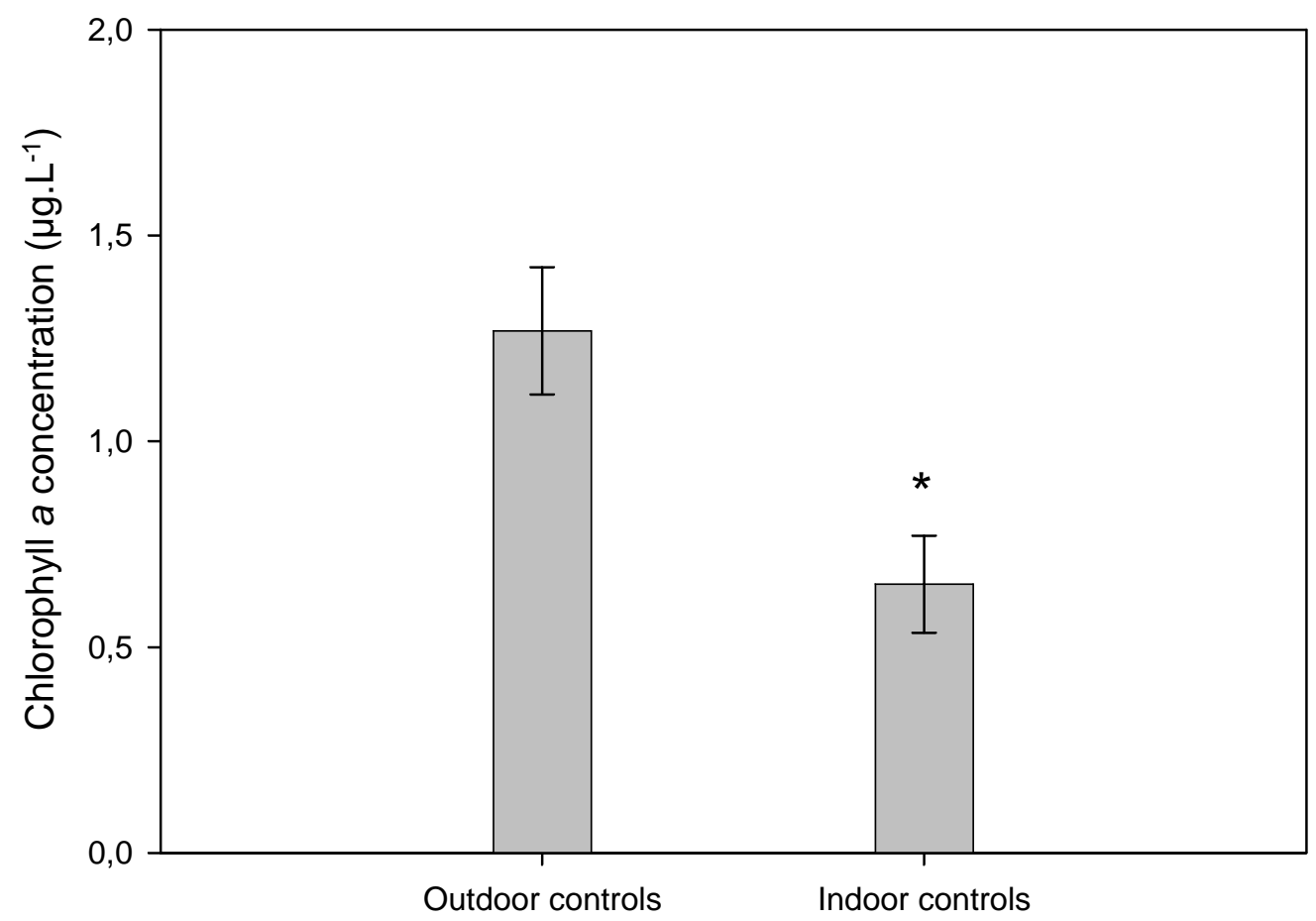


Table 1.

\begin{tabular}{|cccc|}
\cline { 2 - 4 } \multicolumn{1}{c|}{} & $\mathrm{I}(\mathrm{mm})$ & $\mathrm{L}(\mathrm{mm})$ & $\mathrm{Ai}\left(\mathrm{mm}^{2}\right)$ \\
\hline $1^{\text {st }}$ day & $0.89 \pm 0.02$ & $1.05 \pm 0.02$ & $1.01 \pm 0.03$ \\
\hline $13^{\text {th }}$ day & $1.33 \pm 0.02$ & $1.51 \pm 0.02$ & $2.14 \pm 0.07$ \\
\hline
\end{tabular}


Table 2 .

\begin{tabular}{|c|c|c|c|c|c|c|c|c|}
\hline & $\begin{array}{c}\text { Surface } \\
\text { water }\end{array}$ & $\begin{array}{l}\text { Outdoor } \\
\text { Controls }\end{array}$ & $\begin{array}{c}\text { Basamaïs } \\
70 \mu \mathrm{g} \cdot \mathrm{L}^{-1} \\
\text { added }\end{array}$ & $\begin{array}{c}\text { Basamaïs } \\
10 \mu \mathrm{g} . \mathrm{L}^{-1} \\
\text { added }\end{array}$ & $\begin{array}{c}\text { Opus } \\
70 \mu g \cdot \mathrm{L}^{-1} \\
\text { added }\end{array}$ & $\begin{array}{c}\text { Opus } \\
10 \mu g \cdot L^{-1} \\
\text { added }\end{array}$ & $\begin{array}{c}\text { Basamaïs + } \\
\text { Opus } \\
10+10 \mu g . L-1 \\
\text { added }\end{array}$ & $\begin{array}{l}\text { Laboratory } \\
\text { controls }\end{array}$ \\
\hline $\begin{array}{c}\text { Detected } \\
\text { Epoxiconazole }\left(\mu \mathrm{g} \cdot \mathrm{L}^{-1}\right)\end{array}$ & ND & ND & ND & ND & 44.55 & 8.69 & 8.29 & ND \\
\hline $\begin{array}{c}\text { Detected } \\
\text { Bentazone }\left(\mu \mathrm{g} \cdot \mathrm{L}^{-1}\right)\end{array}$ & ND & ND & 45.76 & 7.04 & ND & ND & 6.84 & ND \\
\hline
\end{tabular}


Table 3

Table 3.

\begin{tabular}{|lcc|}
\cline { 2 - 3 } \multicolumn{1}{c|}{} & Outside/Lab Tank & Outside/Underwater \\
\hline Sunny weather & 24 & 11 \\
Cloudy weather & 19 & 10 \\
\hline
\end{tabular}

